Review

\title{
Ten Years of SeaWinds on QuikSCAT for Snow Applications
}

\author{
Annett Bartsch \\ Institute of Photogrammetry and Remote Sensing, Vienna University of Technology, Gusshausstrasse \\ 27-29, Vienna, Austria; Tel.: +43-1-588-011-2221; Fax: +43-1-588-011-2290; \\ E-Mail: ab@ipf.tuwien.ac.at
}

Received: 2 March 2010; in revised form: 24 March 2010 / Accepted: 30 March 2010 /

Published: 16 April 2010

\begin{abstract}
The scatterometer SeaWinds on QuikSCAT provided regular measurements at Ku-band from 1999 to 2009. Although it was designed for ocean applications, it has been frequently used for the assessment of seasonal snowmelt patterns aside from other terrestrial applications such as ice cap monitoring, phenology and urban mapping. This paper discusses general data characteristics of SeaWinds and reviews relevant change detection algorithms. Depending on the complexity of the method, parameters such as long-term noise and multiple event analyses were incorporated. Temporal averaging is a commonly accepted preprocessing step with consideration of diurnal, multi-day or seasonal averages.
\end{abstract}

Keywords: scatterometer; Ku-band; snow; circumpolar

\section{Introduction}

Microwave sensors operating at higher frequencies such as Ku-band (13.4 GHz, $2.1 \mathrm{~cm}$ wavelength) are especially sensitive to changes in snow (e.g., [1,2]). Microwave sensors can be used to detect ongoing snowmelt, whereas the detection capabilities of optical sensors is limited to snow covered area under cloud-free conditions. The exploration of Ku-band scatterometer data started in 1996 with the launch of NSCAT (NASA scatterometer) onboard the Advanced Earth Observation Satellite (ADEOS). Although this type of sensor is designed for ocean applications and the footprint is in the order of $25-50 \mathrm{~km}$, they are attractive for land applications due to the short (several measurements per day at high latitudes) revisit intervals. Thus NSCAT (1996/7) and its follow-up SeaWinds on QuikSCAT (1999-2009) have been used for snowmelt studies. Both are scatterometers, which are real aperture radars. To date there exists no spaceborne SAR (Synthetic Aperture Radar) operating at Ku-band which could allow 
higher spatial resolution analyses. The ten year continuous record from SeaWinds thus provides a unique dataset in spite of the large footprint. This paper reviews characteristics of the data from this specific sensor, processing approaches and change detection methods for snowmelt applications in high latitudes. NSCAT studies are included since all snow application methods are based on analyses of data from this preceding instrument. Applications concentrate on regions mostly above $60^{\circ} \mathrm{N}$. Snowmelt plays an essential role for the hydrological cycle in these regions with significant impact on river runoff timing and magnitude [3]. Changes in river discharge have been reported from several river basins within the last decades [4-6]. The focus of this review is on unglaciated terrain, but several studies also demonstrated the use of Ku-band scatterometer data for ice cap [7,8] and seasonal sea ice monitoring $[9,10]$.

\section{Data Characteristics}

The first Ku-band scatterometer data used for snow studies were acquired by the NSCAT instrument onboard the Advanced Earth Observation Satellite (ADEOS). It was launched in August 1996 and operated until June 1997. The spatial resolution was $25 \mathrm{~km}$ and a $90 \%$ global coverage was achieved within two days. As it was a polar orbiting platform, twice daily acquisitions were available at high latitudes [11]. The later SeaWinds instruments (on QuikSCAT and ADEOS2) also covered 90\% of the Earth's surface daily and provided up to ten measurements towards $75^{\circ} \mathrm{N}$ [12]. SeaWinds on QuikSCAT had also approximately $25 \mathrm{~km}$ spatial resolution and has been in operation for more than ten years from June 1999 [13] to November 2009. It was launched into a polar, sun-synchronous orbit with $98.6^{\circ}$ inclination and with a local equator crossing time at the ascending node of 6:00 am \pm 30 min and a swath width of $1,800 \mathrm{~km}$ [14]. Backscatter measurements were collected simultaneously at constant incidence angles of $46^{\circ}$ for the inner beam, and $54^{\circ}$ for the outer beam, with horizontal and vertical polarizations respectively, using a scanning dish antenna operating at $13.4 \mathrm{GHz}$ (Ku-band). The antenna has an elliptical footprint size of roughly $24 \mathrm{~km} \times 31 \mathrm{~km}$ at inner beam.

Scatterometers are non-imaging radars. An important step in the data preprocessing is therefore the transformation to a discrete grid. Scatterometer data have often been gridded into rectangular cells of e.g., $25 \mathrm{~km} \times 25 \mathrm{~km}$ for NSCAT [15-17] and $10 \mathrm{~km} \times 10 \mathrm{~km}$ for SeaWinds [18, TUW (Vienna University of Technology) product]. This regridding for SeaWinds is carried out either based on Level 2A or Level 1B products of the Jet Propulsion Laboratory (JPL). The Level 1B Product is in temporal order and therefore defined by time boundaries. The Level 2A Product is in spatial order and defined by spatial boundaries [14]. Level $2 \mathrm{~A}$ data contain backscatter measurements representing the elliptical antenna footprint area. Each $\sigma^{0}$ is based on the sum of the echo energies measured among the center high resolution slices in a single scatterometer pulse. The Level 2A Product file also contains flags for land and ice area and it is used, e.g., for the TUW product. An alternative resolution enhanced QuikSCAT product has been developed based on the multiple overlapping measurements available during short time intervals [19]. It is derived from the JPL Level 1B product. In this case $\sigma^{0}$ data are made available as "eggs" or "slices" depending on the actual processing method. Egg-based QuikSCAT images have a nominal pixel spacing of $4.45 \mathrm{~km}$ and an estimated effective resolution of 8-10 km [20, BYU (Brigham Young University) product]. Daily BYU "eggs" data have been used by [21-24], for land applications outside glaciated areas. On a global level these data are assembled from four 
days of data and for polar regions for separated day times due to increased revisit intervals (applied in e.g., [24]). Especially in studies which have been carried out with the BYU product the data are referred to as QSCAT data.

Microwave backscatter in general differs significantly due to changing dielectric properties between frozen and unfrozen ground (e.g., [25-27]). In case of Ku-band, the backscatter is low before snow arrival. It gradually increases with snow accumulation, then rapidly decreases when the snow starts melting. Eventually it increases again when all snow has melted [17](see also Figure 1). A melting snow surface acts similar to a water surface and thus causes specular reflection resulting in the low backscatter values. The level of summer backscatter is lower than winter backscatter. Microwaves emitted at $13.4 \mathrm{GHz}$ penetrate deep into the snow pack in case of dry snow since the grain size is smaller than the wavelength. With increasing snow depth, however, the backscatter is increasing for dry snow [1,28]. Pronounced volume scattering also occurs in case of formation of larger ice crystals, due to metamorphosis after thawing and refreezing [2].

Figure 1. SeaWinds on QuikSCAT timeseries example from autumn 2003 to spring 2004 $\left(\right.$ Salehard, $\left.66.53^{\circ} \mathrm{E}, 66.53^{\circ} \mathrm{N}\right)$. Backscatter of all available measurements in $\mathrm{dB}($ green + ) compared to daily temperature range (red vertical bars show minimum to maximum in degree Celsius; source: WMO D512 dataset). Blue diamonds represent the difference between average morning and evening backscatter in $\mathrm{dB}$.

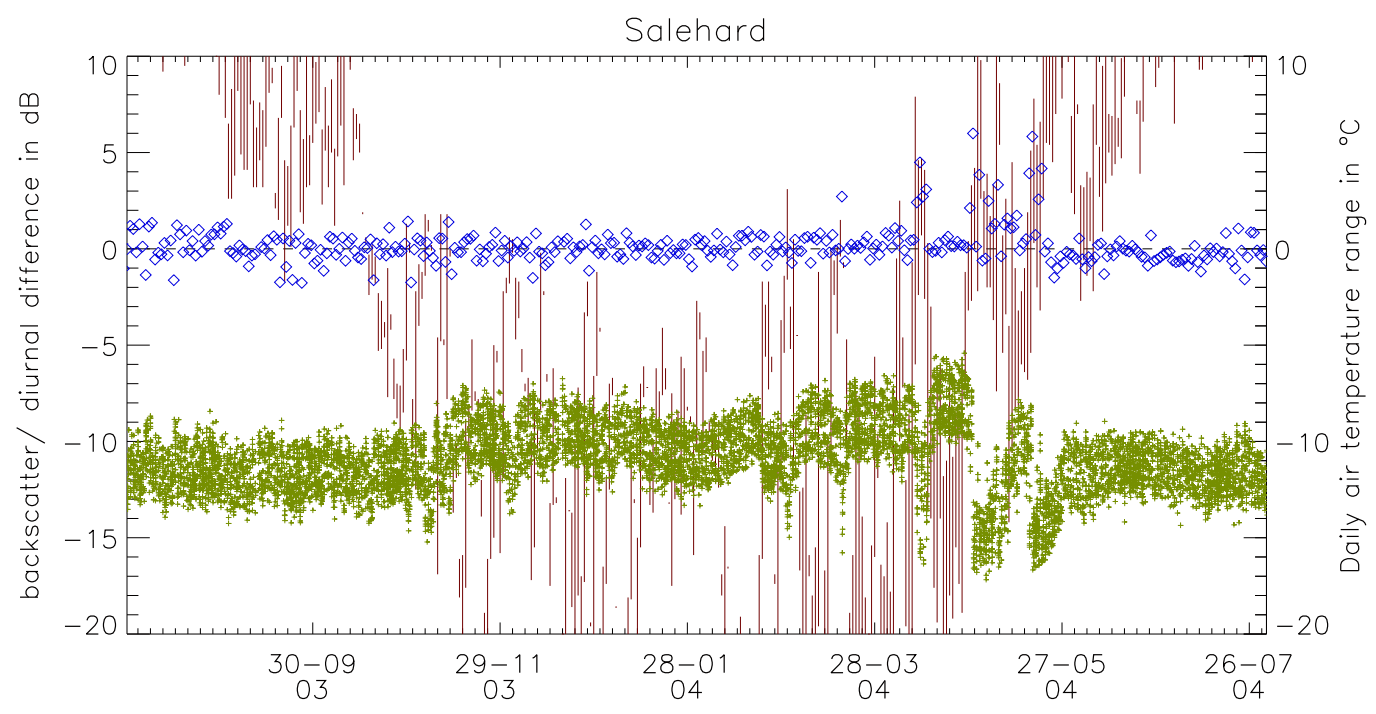

SeaWinds data also exhibit strong temporal variability which varies over differing land cover [12]. The standard deviation of noise $s_{\sigma}$ can be estimated using several months of data as input $[12,18,29]$. Figure 2 demonstrates $s_{\sigma}$ at Ku-band of un-glaciated terrain in high latitudes. It is much higher than $s_{\sigma}$ determined for C-band scatterometry such as MetOp ASCAT in those environments [30]. Typical values are $<0.3 \mathrm{~dB}$ for ASCAT. It usually exceeds $0.5 \mathrm{~dB}$ (mean of 0.57 above $60^{\circ} \mathrm{N}$ ) for SeaWinds. $s_{\sigma}$ varies depending on land cover. It is lowest over forest areas and highest over open water. Large parts of the land area above $60^{\circ} \mathrm{N}$ are characterized by tundra with many small lakes. These areas are generally classified as barren land or sparsely vegetated from global land cover maps (Table 1) and show greater 
Figure 2. Estimated standard deviation of noise in $\mathrm{dB}\left(s_{\sigma}\right)$ of SeaWinds on QuikSCAT above $60^{\circ} \mathrm{N}$ (excluding Greenland).

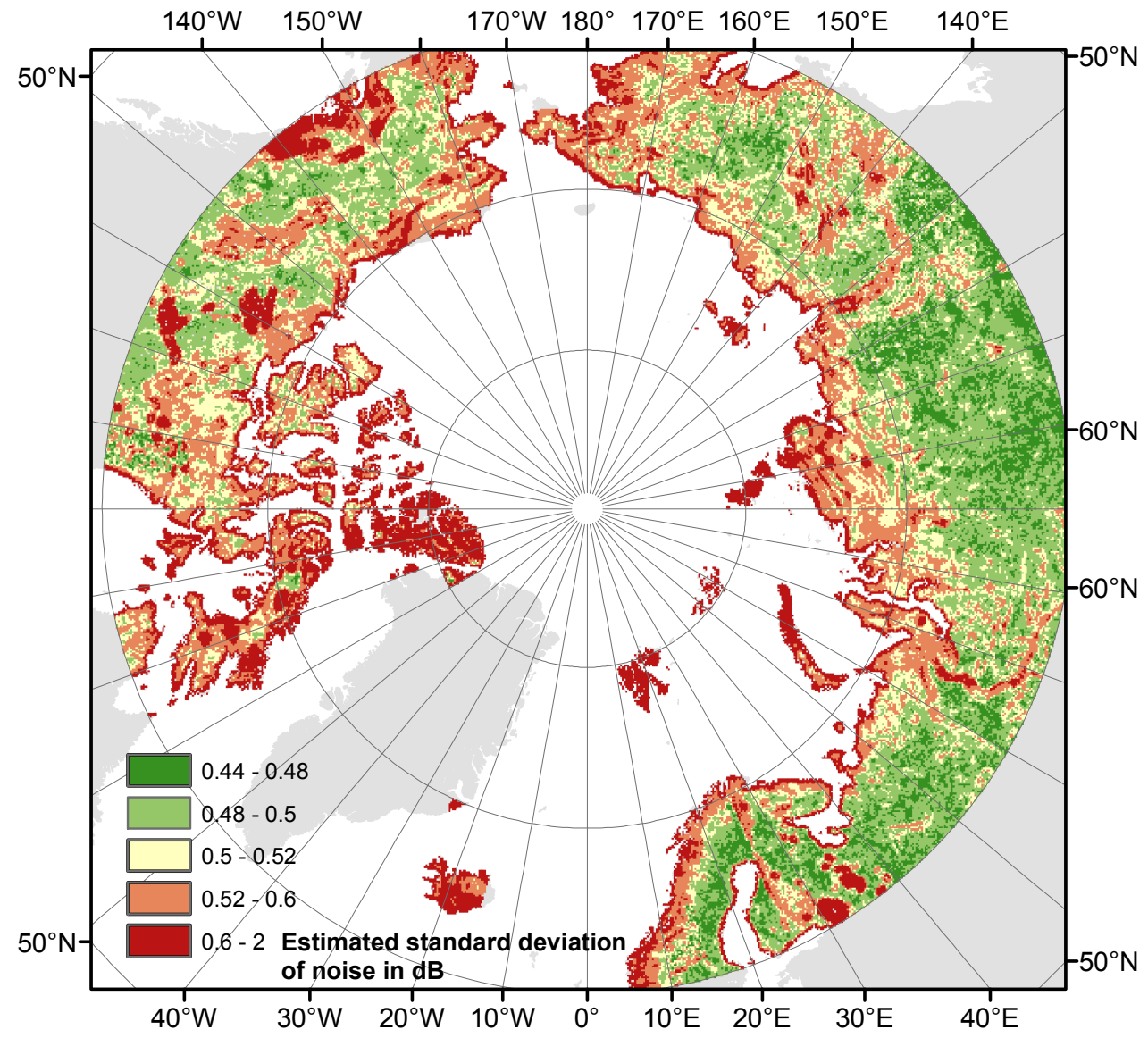

noise than forested regions. This needs to be accounted for especially when change detection methods which use thresholds are applied.

Table 1. Minimum, maximum and mean of estimated standard deviation of noise $s_{\sigma}$ for the predominant major land cover classes (source GlobCover, ionia1.esrin.esa.int).

\begin{tabular}{llll}
\hline GlobCover class & Min & Max & Mean \\
\hline mixed broad leaved and needleaved forest & 0.45 & 0.97 & 0.50 \\
needle leave deciduous or evergreen forest & 0.45 & 1.17 & 0.49 \\
sparse vegetation (less than 15\%) & 0.46 & 1.66 & 0.59 \\
water & 0.48 & 2.46 & 1.98 \\
permanent snow and ice & 0.48 & 2.20 & 0.87 \\
\hline
\end{tabular}




\section{Change Detection Approaches}

The change from snow to snow-free conditions is usually not distinguished from the change from frozen to unfrozen soil conditions when active microwave data are applied in the high latitudes. The term freeze/thaw detection is frequently used in both cases. This may cause confusion on the actual meaning in regions with seasonal snow cover. The snow melt process can take several days to weeks, depending on the snow depth and the continuity of the meteorological conditions leading to the melt. Advanced change detection approaches thus need to also consider multiple thaw periods. This differs for the detection of mid-winter melt events or melt days on ice caps. In such cases each single day needs to be detected.

Although the available record of NSCAT is rather short (eleven months) it provided a first dataset covering an entire northern hemisphere winter and spring period at this wavelength (Table 2). Its suitability for detection of freeze/thaw was tested by [11]. They introduced a change detection algorithm which considers differences between five day averages (separately for morning and evening measurements) and location specific differences from the overall mean value. They discussed also an approach previously developed for C-band scatterometry [31]. This method is based on the typical summer (July) and winter (February) backscatter level in order to determine the thaw timing. When a minimum of $50 \%$ of the winter-summer difference is exceeded for at least two consecutive measurements ground thaw is detected. In case of NSCAT summer backscatter was determined based on June measurements since it stopped operating during that month. It has been stressed that the backscatter signal is increasing after melt at C-band and decreasing at Ku-band. The C-band method can therefore not be directly applied. This first NSCAT study at three sites in Canada [11] was extended for a number of follow-up studies with Ku-band scatterometry. Kimball et al. [15] adapted the C-band freeze thaw classifier of [31,32] to NSCAT data over Alaska. The five day average method from [11] was extended for NSCAT by extraction of three specific dates of thaw: the start, the end and the primary thaw date which is the day with the largest negative backscatter difference and applied over part of Canada [16].

The five day moving average approach has been subsequently transferred to QuikSCAT (launched 1999) for final thaw date extraction and also applied in a similar way to autumn refreeze over Alaska for the years 2000 and 2001 [33]. The investigation has been then extended for application on circumpolar scale [34]. A further method considers winter (February) mean backscatter applying fixed thresholds for daily mean values in order to determine the onset of snowmelt over the Canadian Arctic for the years 2000-2004 [23]. A fixed value for melt duration (23 days) has been added to determine the end of snowmelt. As QuikSCAT provides sufficient morning and evening measurements, a new adaptive approach based on diurnal thaw and refreeze of snow cover could be developed [12,18, TUW method]. The algorithm was initially setup over central Siberia covering the years 2000-2004. Thresholds are defined for each single grid cell dependent on the estimated standard deviation of long-term noise (Figure 2) and the actual number of measurements available during each 12 hour period. Significant diurnal backscatter changes occur throughout the snowmelt period several times but not necessarily on subsequent days. This occurrence of multiple events has been solved with a clustering method. In case of multiple melt periods (several clusters of at minimum two days with diurnal thaw and refreeze), the last one is identified as the major melt period $[35,36]$. 
Table 2. Methods and parameters of spring snowmelt products from spaceborne scatterometers.

\begin{tabular}{|c|c|c|c|}
\hline Reference & Sensor & Method & Parameters \\
\hline $\begin{array}{l}\text { [31] Boehnke \& } \\
\text { Wismann } 1996\end{array}$ & $\begin{array}{l}\text { ERS } \\
\text { (C-band) }\end{array}$ & $\begin{array}{l}\text { Location specific summer (July) } \\
\text { and winter (February) backscatter }\end{array}$ & Thaw timing \\
\hline $\begin{array}{l}\text { [11] Frolking et al. } \\
1999\end{array}$ & NSCAT & $\begin{array}{l}\text { Five day average backscatter and } \\
\text { location specific difference from } \\
\text { overall mean }\end{array}$ & Thaw timing \\
\hline $\begin{array}{l}\text { [15] Kimball et al. } \\
2001\end{array}$ & NSCAT & $\begin{array}{l}\text { Application of similar method as in } \\
\text { Boehnke et al. } 1996\end{array}$ & Thaw timing \\
\hline $\begin{array}{l}\text { [18] Kidd et al. 2003, } \\
\text { [12] Bartsch et al. } 2007\end{array}$ & $\begin{array}{l}\text { SeaWinds } \\
\text { QuikSCAT }\end{array}$ & $\begin{array}{l}\text { Diurnal differences with respect to } \\
\text { noise and multiple thaw periods }\end{array}$ & $\begin{array}{l}\text { Start and end } \\
\text { of major thaw } \\
\text { period }\end{array}$ \\
\hline $\begin{array}{l}\text { [16] Kimball et al. } \\
\text { 2004a }\end{array}$ & NSCAT & Extension of Frolking et al. 1999 & $\begin{array}{l}\text { Start, end, } \\
\text { primary thaw } \\
\text { date }\end{array}$ \\
\hline $\begin{array}{l}\text { [33] Kimball et al. } \\
\text { 2004b }\end{array}$ & $\begin{array}{l}\text { SeaWinds } \\
\text { QuikSCAT }\end{array}$ & As in Kimball et al. 2004a & $\begin{array}{l}\text { Start, end, } \\
\text { primary thaw } \\
\text { date plus autumn } \\
\text { refreeze }\end{array}$ \\
\hline [23] Brown et al. 2007 & $\begin{array}{l}\text { SeaWinds } \\
\text { QuikSCAT }\end{array}$ & $\begin{array}{l}\text { Fixed threshold for deviation from } \\
\text { winter (February) backscatter level }\end{array}$ & Thaw timing \\
\hline [24] Wang et al. 2008 & $\begin{array}{l}\text { SeaWinds } \\
\text { QuikSCAT }\end{array}$ & $\begin{array}{l}\text { Application of method from } \\
\text { Frolking et al. } 1999 \text { to average } \\
\text { evening backscatter with respect to } \\
\text { summer mean values (August) }\end{array}$ & Snow-off date \\
\hline
\end{tabular}

An analysis limited to evening measurements using the five day average approach [11] plus the summer mean backscatter (August) has been carried out on pan-arctic scale for 2000-2005 by [24]. The evening values have been taken from the BYU "egg" product [20]. Static thresholds were used for snow-off day definitions and it is assumed that relevant melt periods are longer than two days. If multiple events occur, the longest period has been selected. This does not account for short term interruptions and thus classifies the end of melt only with respect to the entire spring melt period.

More advanced scatterometer-based products include snow covered area and melt area. The snow covered area can be determined with all above mentioned approaches as well as with optical data [37]. The melt area can be derived with the methods of [15] or [12] as they consider beginning and end of spring thaw. This differs from glaciological applications where single days or consecutive days with surface melt need to be identified for melt season length determination (e.g., [8]) as any interruption of melt may impact the mass balance. Surface melt of seasonal snow cover, especially in relation to 
rain-on-snow events, affects thermal properties of the snow pack and the soil beneath [38]. Even single days of thaw during spring can cause an increase in heterotrophic soil respiration [12]. The primary thaw day [15] extracted for the year 2000 in the circum-boreal and -arctic regions showed good correlations $(\mathrm{R}=0.75)$ with modelled timing of water content increase in the snowpack [34]. The temporal evolution of the area which undergoes snowmelt at a certain time influences the spring river discharge patterns of high latitude basins [39].

Current approaches are not applicable in regions where no continuous snow cover/frozen ground conditions during the winter time exists as they are designed to identify one seasonal thaw event or period only. The presence of snow itself is not considered in all approaches. The presence of melting snow causes decreased backscatter similar to water in both C-band and Ku-band. Multiple thaw periods can occur within the same winter season at all latitudes. This needs to be accounted for independent whether ground thaw or snow thaw should be detected. This has been so far considered in two mapping approaches only [12,24]. The for QuikSCAT typical variations in noise are only directly accounted for by the TUW method $[12,18]$. Noise is in general reduced by averaging over several days.

Figure 3. Frequency of midwinter daily average backscatter increases of more than 1.5 $\mathrm{dB}$ as detected with Ku-band QuikSCAT for the months November to February of winter 2000/1-2008/9 (no masking applied for lakes).

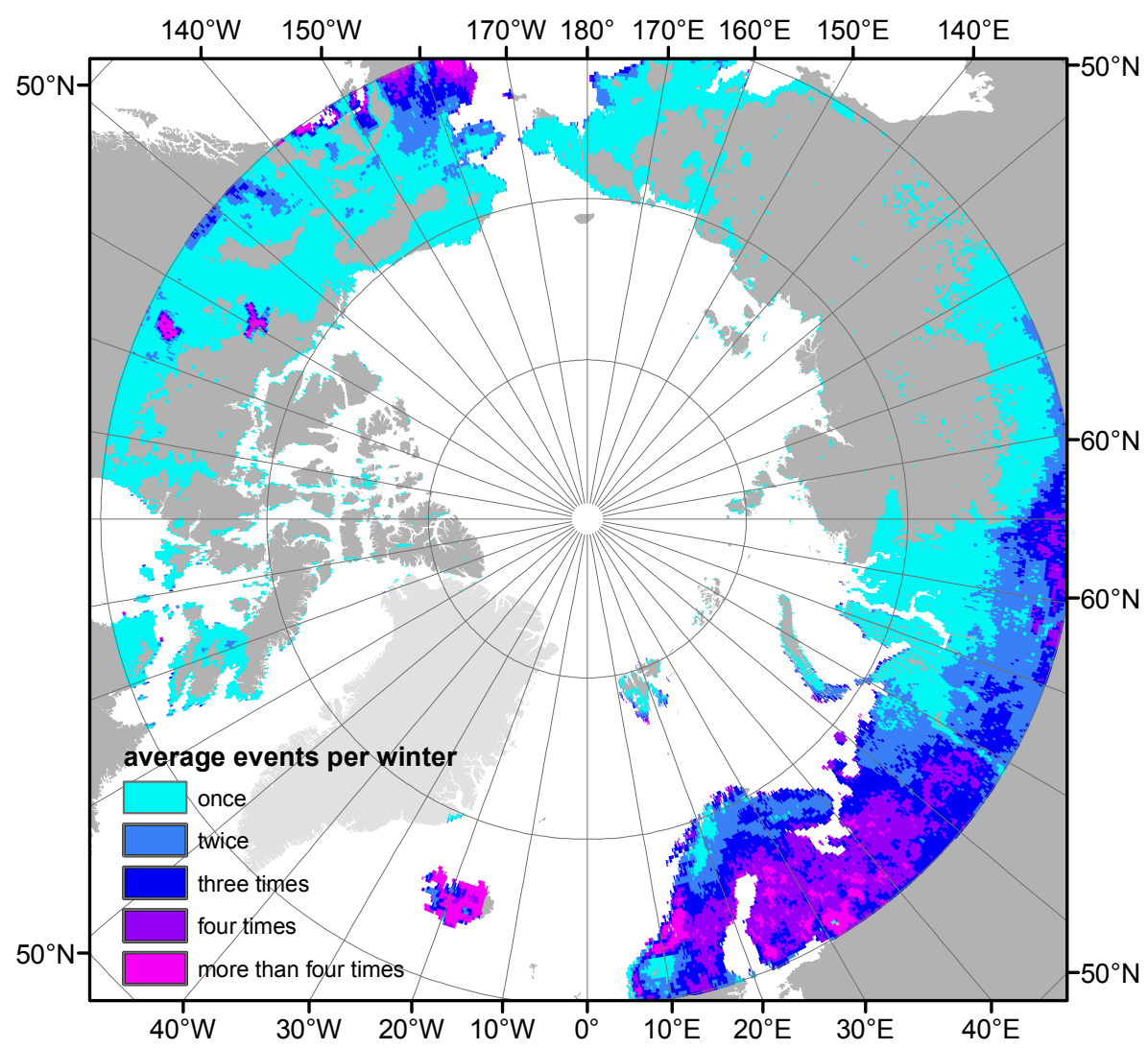

As shown in Figure 3, melt events can also occur during mid winter and are followed by freeze up with Ku-band backscatter increase. These backscatter events are described by [11] for NSCAT. In 
order to determine how often such events actually occur the backscatter difference $\Delta \sigma_{t}^{0}$ on day $t$ can be extracted considering, e.g., a three day window before and after the event [40]. A significant change due to thaw and refreeze can be assumed for a threshold of $1.5 \mathrm{~dB}$, which equals approximately three times the typical estimated standard deviation of noise $s_{\sigma}$. Figure 3 shows the number of events captured over un-glaciated terrain in high latitudes (above $60^{\circ}$ North) during the months from November to February for the entire ten year record.

\section{Applications}

Air temperature measurements at meteorological stations are the foremost ground data source for the assessment of snow melt related QuikSCAT products. A temperature increase relates to melt events during the winter [40] as well as during spring (e.g., [11,15]). The mid-winter backscatter change is often a result of rain-on-snow events. A general increase of air temperature above zero degree Celsius corresponds to backscatter changes in spring. Backscatter drops as soon as the daily maximum air temperature exceeds zero degrees Celsius and increases to summer level when minimum daily air temperatures rise above freezing [12]. Snowdepth records can be also suitable for the assessment of the end of snowmelt $[11,12,24]$. Snow distribution can however vary within the large footprint and station point data are less representative. [24] found an agreement of the end of snowmelt with snow depth records within \pm 7 days for more than $90 \%$ of analyzed meteorological station measurements. The relatively large sensor footprint size becomes more of a constraint in mountainous areas.

The timing of snowmelt is related to $\mathrm{CO}_{2}$ fluxes [41]. QuikSCAT products have therefore been compared to eddy flux tower [12] and xylum sap flow measurements [16], and (Gross Primary Production) GPP estimates [33]. A flux increase above winter levels (release of carbon) starts as soon as the snow starts melting. The following switch from $\mathrm{CO}_{2}$ source to sink is close to the end of seasonal snowmelt [36].

Mid-winter short term melt events have severe impact on wild life. Ungulates such as reindeer and caribou need to dig through the snow layer to reach their winter forage beneath. Ice crusts form when the snow refreezes after rain-on-snow events. This snow grain metamorphosis after thawing and refreezing $[2,42]$ results in a significant increase of Ku-band backscatter as discussed in the previous section. SeaWinds has been used to assess the temporal frequency and extent of such events under the view point of reindeer herding over Northern Eurasia from 2000 to 2008 [40]. In this case also human communities which depend on reindeer herding are affected. Midwinter events over $60^{\circ} \mathrm{N}$ are most common in western Siberia, Scandinavia and parts of Alaska (see Figure 3). They are less frequent in the Canadian Arctic and central to east Siberia. They are however predicted to increase over central Siberia [43].

Snow cover information is also required for permafrost distribution modeling (e.g., [44,45]). Its dynamics impact albedo and it insulates the ground. The timing of steady snow cover destruction also coincides with the rise of land surface temperature above zero degree Celsius and thus the initiation of seasonal active layer thaw.

Rawlins et al. [34] used the threshold based method of [16,33] to detect the incipient thaw timing with SeaWinds. Results have been compared to modelled snow water increase over a number of North American basins. Almost 50\% of the Pan-Arctic area shows a difference of less than a week between 
Figure 4. Ten years (2000-2009) of spring snow melt dynamics based on diurnal thaw and refreeze detection [12]: (a) mean day of snowmelt start, (b) mean day of snowmelt end, (c) standard deviation of start of snowmelt in days, (d) standard deviation of end of snowmelt in days, (e) mean duration of spring snowmelt period, (f) standard deviation of spring snowmelt duration.
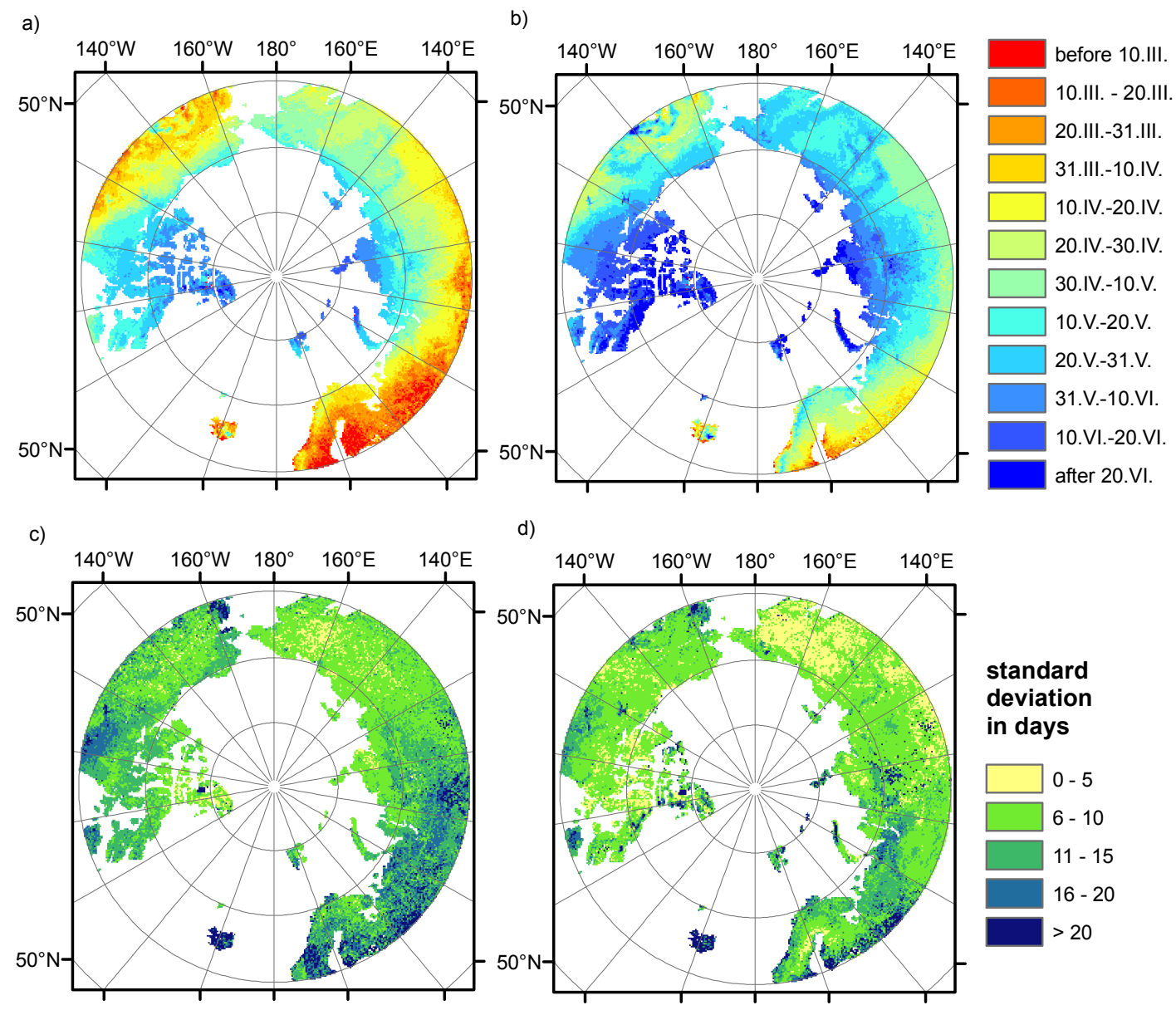

d)

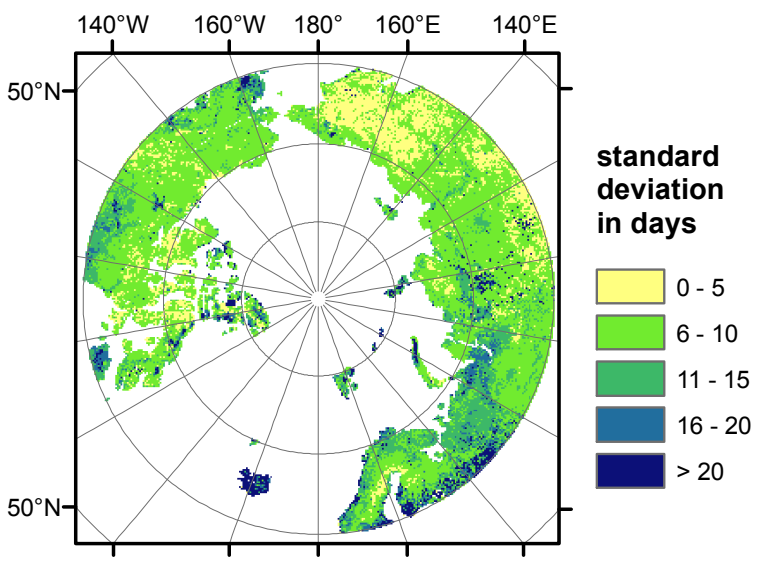

e)

f)

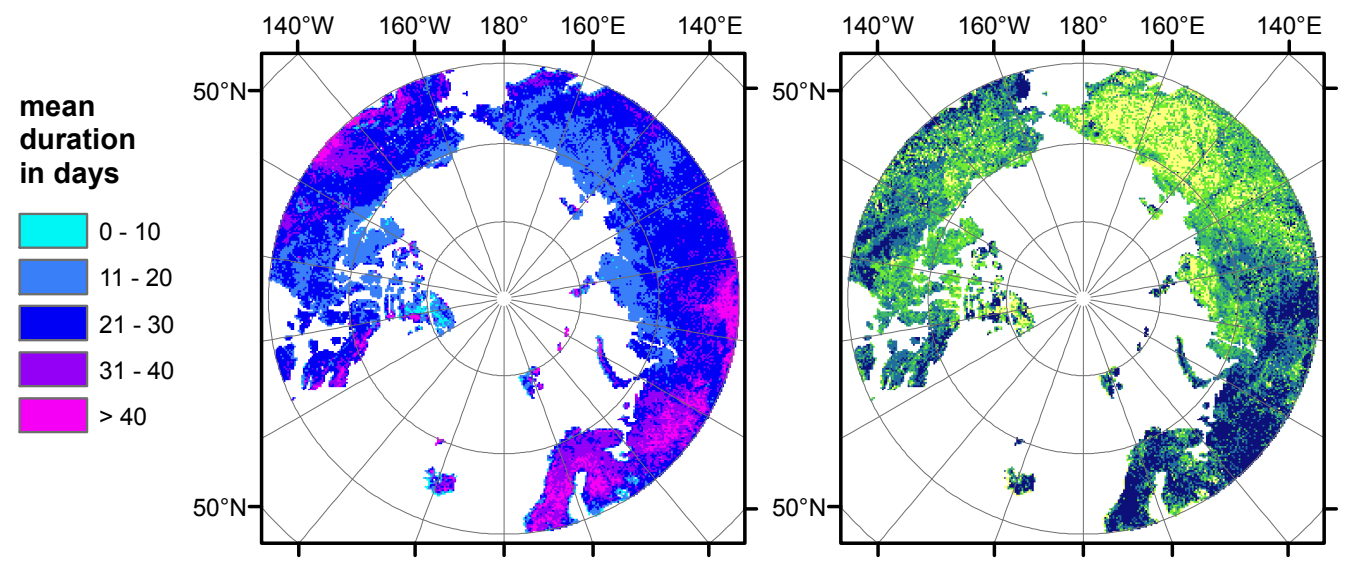

primary thaw from QuikScat and modelled snow water increase. Spring flooding has been also related to melt patterns detected with Ku-band scatterometry [17]. 
To date no extensive direct comparisons between different SeaWinds snowmelt products have been made. Snowmelt dates have also been compared to ground measurements of onset of xylem sap flow in pine trees at five sites in Alaska for the years 2000 and 2001 [16]. Those results have been compared to the beginning and end of diurnal thaw and refreeze cycling [12]. The end of diurnal cycling gave best agreement with the onset of xylum sap flow. The actual deviation differs for the two years for both QuikSCAT products. The difference in days (between -15 and +15) was in nine of ten cases smaller for the diurnal cycling method [12] than the threshold based method [16]. The number of samples were however too low to draw general conclusions. Snowmelt timing statistics for the ten years of data availability based on [12] are shown in Figure 4.

Bartsch et al. [36] assessed different spring timing products from the Siberia II project. The Siberia II project dealt with multi-sensor concepts for greenhouse gas accounting in central Siberia [46]. The different approaches within the project identified three different phases of the spring thaw, specially identifying the end of snow melt from active microwave data (SeaWinds, [12]), free snow condition from passive microwave data (SSM/I, [47]) and the onset of green up/budburst based on optitcal multispectral data (SPOT-VGT, [48]). Whereas the SeaWinds product provides daily information, SSM/I was averaged over 5 days and the SPOT-VGT was available in 10 day intervals. These differences in temporal resolution in addition to issues of spatial resolution allow only limited comparability. Considering a \pm 10 day variation, $80 \%$ of the central Siberian study region (3 Mio $\mathrm{km}^{2}$, stretching from Taimyr to Lake Baikal) showed agreement between SeaWinds and SSM/I end of snowmelt [36]. SSM/I snowmelt timing tends to be earlier than the end of daily freeze/thaw cycling. The average offset between the SPOT-VGT greening up dates was 1-2 weeks, indicating that the end of diurnal thaw and refreeze from SeaWinds is also representative for budburst within Taiga forest with moderate terrain. Brown et al. [23] compared QSCAT derived snowmelt with the daily $24 \mathrm{~km}$ resolution Interactive Multisensor Snow and Ice Mapping System (IMS) product and a snow water equivalent (SWE) product (SSM/I, [49]) based on passive microwave. Best performance was found for IMS and QSCAT, although the duration of the melt period has been assumed to be static.

\section{Summary}

SeaWinds (1999-2009) seasonal snow melt studies largely build upon previous experience with NSCAT (1996/1997). Additionally approaches developed for the C-band scatterometers (ERS1/2, 1992 onwards) have been considered, although they operate at a longer wavelength with different snow scattering properties from Ku-band scatterometry. The sensitivity of backscatter to changes in liquid water content of the snow surface is exploited in both wavelengths.

NSCAT analyses for seasonal snow applications started over Alaska and Canada. First application of QuikSCAT data was published for Siberia [18] followed by studies over Canada and Alaska and eventually on circum-polar scale [24,34]. Comprehensive processing of SeaWinds L2A and L1B data have been carried out in cooperation with NASA JPL (e.g., [11,16]), by TUW (e.g., [12,18]) and BYU (e.g., $[23,24])$.

Whereas passive microwave sensors are used to determine geophysical parameters such as SWE, the $\mathrm{Ku}$-band scatterometer is to date only used for change detection analyses intended for identification of freeze-thaw characteristics for specific days of the year. This is achieved by definition of thresholds 
for the backscatter deviation from long-term, seasonal, multi-day or diurnal averages. Static as well as adaptive measures are applied. An adaptive threshold is for example defined as multiples of the standard deviation of location specific noise [12] or seasonal variation [11].

Most studies have focused on high latitudes, since continuous snow cover and higher number of observations benefit time series analyses in that region. Sufficient snow depth and limited evaporation are also required for a distinctive snow melt signal. Derived parameters which relate to spring snowmelt are the start, duration and end of snowmelt (or snow-off day). Days with maximum deviations are defined as primary thaw days [16]. Single melt days during winter do not necessarily show a backscatter decrease during events (such as rain-on-snow) but result in later backscatter increase when the snow surface is refreezing. This allows for the detection of thaw and refreeze days [40]. The detection of autumn refreeze has been attempted only in one case [33] as this change is less distinctive in Ku-band. Beside its use for seasonal snowmelt detection, SeaWinds has been also investigated at high latitudes for glaciological studies over Greenland [7,8], lake ice phenology [50] and sea ice monitoring [9,10,51].

Although the QuikScat mission stopped on November 23, 2009 due to antenna problems it provides a valuable dataset. A full decade of data is now available which gives insight into the spatial variability of snowmelt on circumpolar scale (Figure 4). The record is too short in order to access significant trends and the interannual variability is large. The type of satellite data employed (scatterometer) provides rather coarse spatial resolution maps, but better than daily data.

$\mathrm{Ku}$-band and also X-band have been identified as most suitable for snow applications and are considered for possible future SAR satellite missions which are dedicated to snow monitoring [52]. A Ku-band scatterometer for the purpose of ocean wind detection is also aboard Oceansat II (launched by the Indian Space Research Organisation on September 23, 2009; http://database.eohandbook.com/, status March 2010). Surface melt and refreeze patterns can, however, be also observed with C-band as demonstrated by [32]. C-band scatterometry such as the recently launched Metop ASCAT offer near real time mapping capability [53] at similar resolution like SeaWinds. A similar Ku-band sensor which will additionally acquire in C-band (Dual Frequency Scatterometer: DFS) is in preparation by the National Oceanic and Atmospheric Administration (NOAA) in cooperation with the Jet Propulsion Laboratory (JPL) and the Japan Aerospace Exploration Agency (JAXA) for launch in 2016 as part of the Global Climate Observation Mission-W2 [54].

\section{Acknowledgements}

This study has been funded by a Hertha Firnberg research fellowship (Austrian Science Fund, T322-N10).

\section{References}

1. Ulaby, F.T; Stiles, W.H. The Active and Passive Microwave Response to Snow Parameters 2. Water Equivalent of Dry Snow. J. Geophys. Res. 1980, 85, 1045-1049.

2. Mätzler, C.; Schanda, E. Snow Mapping with Active Microwave Sensors. Int. J. Remote Sens. 1984, 5, 409-422. 
3. Yang, D.; Zhao, Y.; Armstrong, R.; Robinson, D.; Brodzik, M.J. Streamflow Response to Seasonal Snow Cover Mass Changes over Large Siberian Watersheds. J. Geophys. Res. 2007, 112, F02S22.

4. Yang, D.; Ye, B.; Kane, D.L. Streamflow Changes over Siberian Yenisei River Basin. J. Hydrol. 2004, 296, 59-80.

5. Muskett, R.R.; Romanovsky, V.E. Groundwater Storage Changes in Arctic Permafrost Watersheds from GRACE and in situ Measurements. Env. Res. Lett. 2009, 4, 045009.

6. Shiklomanov, A.I.; Lammers, R.B. Record Russian River Discharge in 2007 and the Limits of Analyses. Env. Res. Lett. 2009, 4, 045015.

7. Nghiem, S.V.; Steffen, K.; Kwok, R.; Tsai, W.Y. Detection of Snow Melt Regions on the Greenland Ice Sheet Using Diurnal Backscatter Change. J. Glaciol. 2001, 47, 539-547.

8. Tedesco, M. Snowmelt Detection over the Greenland Ice Sheet from SSM/I Brightness Temperature Daily Variations. Geophys. Res. Lett. 2007, 34, L02504.

9. Nghiem, S.V.; Chao, Y.; Neumann, G.; Li, P.; Perovich, D.K.; Street, T.; Clemente-Colon, P. Depletion of Perennial Sea Ice in the East Arctic Ocean. Geophys. Res. Lett. 2006, 33, L17501.

10. Yu, P.; Clausi, D.A.; Howell, S.E.L. Fusing AMSR-E and QuikSCAT Imagery for Improved Sea Ice Recognition. IEEE Trans. Geosci. Remote Sens. 2009, 47, 1980-1989.

11. Frolking, S.; McDonald, K.C.; Kimball, J.S.; Way, J.B.; Zimmermann, R.; Running, S.W. Using the Space-Borne NASA Scatterometer (NSCAT) to Determine the Frozen and Thawed Seasons. $J$. Geophys. Res. 1999, 104, 27895-27907.

12. Bartsch, A.; Kidd, R.A.; Wagner, W.; Bartalis, Z. Temporal and Spatial Variability of the Beginning and End of Daily Spring Freeze/Thaw Cycles Derived from Scatterometer Data. Remote Sens. Environ. 2007, 106, 360-374.

13. Tsai, W.T.; Nghiem, S.V.; Huddleston, J.N.; Spencer, M.W.; Stiles, B.W.; West, R.D. Polarimetric Scatterometry: A Promising Technique for Improving Ocean Surface Wind Measurements from Space. IEEE Trans. Geosci. Remote Sens. 2000, 38, 1903-1921.

14. Callahan, P.S. QuikSCAT Science Data Product Users Manual, Overview and Geophysical Data Products; Version 3.0, JPL: Pasadena, CA, USA, 2006; D-18053-RevA.

15. Kimball, J.S.; McDonald, K.C.; Keyser, A.R.; Frolking, S.; Running, S.W. Application of the NASA Scatterometer (NSCAT) for Determining the Daily Frozen and Nonfrozen Landscape of Alaska. Remote Sens. Environ. 2001, 75, 113-126.

16. Kimball, J.S.; McDonald, K.C.; Frolking, S.; Running, S.W. Radar Remote Sensing of the Spring Thaw Transition Across a Boreal Landscape. Remote Sens. Environ. 2004, 89, 163-175.

17. Nghiem, S.V.; Tsai, W.Y. Global Snow Cover Monitoring with Spaceborne Ku-Band Scatterometer. IEEE Trans. Geosci. Remote Sens. 2001, 39, 2118-2134.

18. Kidd, R.A.; Trommler, M.; Wagner, W. The Development of a Processing Environment for Time-Series Analyses of SeaWinds Scatterometer Data. In Proceedings of IEEE 2003 International Geoscience and Remote Sensing Symposium, Toulouse, France, 2003; pp. 4110-4112.

19. Early, D.S.; Long, D.G. Image Reconstruction and Enhanced Resolution Imaging from Irregular Samples. IEEE Trans. Geosci. Remote Sens. 2001, 39, 291-302. 
20. Long, D.G.; Hicks, B.R. Standard BYU QuikSCAT/SeaWinds Land/Ice Image Products; MERS Technical Report 05-04, Brigham Young University: Provo, UT, USA, 2005.

21. Hardin, P.J.; Jackson, M.W. Investigating SeaWinds Terrestrial Backscatter: Equatorial Savannas of South America. Photogramm. Eng. Remote Sens. 2003, 69, 1243-1254.

22. Frolking, S.; Fahnestock, M.; Milliman, T.; McDonald, K.; Kimball, J. Interannual Variability in North American Grassland Biomass/Productivity Detected by SeaWinds Scatterometer Backscatter. Geophys. Res. Lett. 2005, 32, L21409.

23. Brown, R.; Derksen, C.; Wang, L. Assessment of Spring Snow Cover Duration Variability over Northern Canada From Satellite Dataset. Remote Sens. Environ. 2007, 111, 367-381.

24. Wang, L.; Derksen, C.; Brown, R. Detection of Pan-Arctic Terrerstrial Snowmelt from QuikSCAT, 2000-2005. Remote Sens. Environ. 2008, 112, 3794-3805.

25. Ulaby, F.T.; Moore, R.K.; Fung, A. Microwave Remote Sensing-Active and Passive; Artech House: Norwood, MA, USA, 1982; Volume II.

26. Way, J.B.; Zimmermann, R.; Rignot, E.; McDonald, K.; Oren, R. Winter and Spring Thaw as Observed with Imaging Radar at BOREAS. J. Geophys. Res. 1997, 102, 29673-29684.

27. Wegmüller, U. The Effect of Freezing and Thawing on the Microwave Signatures of Bare Soil. Remote Sens. Environ. 1990, 33, 123-135.

28. Tedesco, M.; Miller, J. Observations and Statistical Analysis of Combined Activepassive Microwave Space-Borne Data and Snow Depth at Large Spatial Scales. Remote Sens. Environ. 2007, 111, 382-397.

29. Wagner, W.; Lemoine, G.; Rott, H. A Method for Estimating Soil Moisture from ERS Scatterometer and Soil Data. Remote Sens. Environ. 1999, 70, 191-207.

30. Naeimi, V.; Scipal, K.; Bartalis, Z.; Hasenauer, S.; Wagner, W. An Improved Soil Moisture Retrieval Algorithm for ERS and METOP Scatterometer Observations. IEEE Trans. Geosci. Remote Sens. 2009, 47, 1999-2013.

31. Boehnke, K.; Wismann, V.R. ERS Scatterometer Land Applications: Detecting the Thawing of Soils in Siberia; Earth Observation Quarterly 52, ESA Publication Division: Noordwijk, The Netherlands, 1996.

32. Wismann, V. Monitoring of Seasonal Thawing in Siberia with ERS Scatterometer Data. IEEE Trans. Geosci. Remote Sens. 2000, 38, 1804-1809.

33. Kimball, J.S.; McDonald, K.C.; Running, S.W.; Frolking, S.E. Satellite Radar Remote Sensing of Seasonal Growing Seasons for Boreal and Subalpine Evergreen Forests. Remote Sens. Environ. 2004, 90, 243-258.

34. Rawlins, M.A.; McDonald, K.C.; Frolking, S.; Lammers, R.B.; Fahnestock, M.; Kimball, J.S.; Vörösmarty, C.J. Remote Sensing of Snow Thaw at the Pan-Arctic Scale Using the SeaWinds Scatterometer. J. Hydrol. 2005, 312, 294-311.

35. Bartsch, A.; Kidd, R.; Wagner, W. Diurnal Thaw and Refreeze During Spring Snowmelt from Quikscat over Entire Siberia. In Proceedings of the 5th EARSEL Workshop on Remote Sensing of Snow and Glaciers: Changing Climate Changing Cryosphere, Bern, Switzerland, February 2008. 
36. Bartsch, A.; Wagner, W.; Kidd, R. Remote Sensing of Spring Snowmelt in Siberia. In Environmental Change in Siberia. Earth Observation, Field Studies and Modelling; Balzter, H., Ed.; Springer: Dordrecht, The Netherlands, 2010.

37. Scherer, D.; Hall, D.K.; Hochschild, V.; König, M.; Winther, J.G.; Duguay, C.R.; Pivot, F.; Mätzler, C.; Rau, F.; Seidel, K.; Solberg, R.; Walker, A.E. Remote Sensing of Snow Cover. In Remote Sensing in Northern Hydrology: Measuring Environmental Change; Duguay, C.R., Pietroniro, A., Eds; American Geophysical Union: Washington, DC, USA, 2005; Volume 163, Geophysical Monograph Series, pp. 7-38.

38. Putkonen, J.; Roe, G. Rain-on-Snow Events Impact Soil Temperatures and Affect Ungulate Survival. Geophys. Res. Lett. 2003, 30, 1188.

39. Bartsch, A.; Wagner, W.; Rupp, K.; Kidd, R. Application of C and Ku-Band Scatterometer Dara for Catchment Hydrology in Northern Latitudes. In Proceedings of the 2007 IEEE International Geoscience and Remote Sensing Symposium, Barcelona, Spain, July 2007.

40. Bartsch, A.; Kumpula, T.; Forbes, B.; Stammler, S. Detection of Snow Surface Thawing and Refreezing in the Eurasian Arctic Using QuikSCAT: Implications for Reindeer Herding. Ecol. Appl. 2010, e-View, doi: 10.1890/09-1927, (in press).

41. Aurela, M.; Laurilla, T.; Tuovinen, J.P. The Timing of Snow Melt Controls the Annual CO2 Balance in a Subarctic Fen. Geophys. Res. Lett. 2004, 31, L16119.

42. Rees, W.G. Remote Sensing of Snow and Ice; CRC Press: Boca Raton, FL, USA, 2006.

43. Ye, H.; Yang, D.; Robinson, D. Winter Rain on Snow and its Association with Air Temperature in Northern Eurasia. Hydrol. Proc. 2008, 22, 2728-2736.

44. Stieglitz, M.; Dery, S.J.; Romanovsky, V.E.; Osterkamp, T.E. The Role of Snow Cover in the Warming of Arctic Permafrost. Geophys. Res. Lett. 2003, 30, 1721.

45. Saito, K.; Kimoto, M.; Takata, T.Z.A.K.; Emori, S. Evaluating a High-Resolution Climate Model: Simulated Hydrothermal Regimes in Frozen Ground Regions and their Change under the Global Warming Scenario. J. Geophys. Res. 2007, 112, F02S11.

46. Schmullius, C.; Hese, S.; Knorr, D. Siberia-II - A Multi Sensor Approach for Greenhouse Gas Accounting in Northern Eurasia. Petermanns Geographische Mitteilungen 2003, 47, 4-5.

47. Grippa, M.; Kergoat, L.; Le Toan, T.; Mognard, N.M.; Delbart, N.; L'Hermitte, J.; Vincente-Serrano, S.M. The Impact of Snow Depth and Snowmelt on the Vegetation Variability over Central Siberia. Geophys. Res. Lett. 2005, 32, L21412.

48. Delbart, N.; Kergoat, L.; Le Toan, T.; Lhermitte, J.; Picard, G. Determination of Phenological Dates in Boreal Regions Using Normalized Difference Water Index. Remote Sens. Environ. 2005, 97, 26-38.

49. Derksen, C.; A, W. Identification of Systematic Bias in the Crossplatform (SMMR and SSM/I) EASE-Grid Brightness Temperature Time Series. IEEE Trans. Geosci. Remote Sens. 2003, 41, 910-915.

50. Howell, S.E.L.; Brown, L.C.; Kang, K.K.; Duguay, C.R. Variability in Ice Phenology on Great Bear Lake and Great Slave Lake, Northwest Territories, Canada, from SeaWinds/QuikSCAT: 20002006. Remote Sens. Environ. 2009, 113, 816-834. 
51. Haarpaintner, J. Arctic-Wide Operational Sea Ice Drift From Enhanced-Resolution QuikScat/ SeaWinds Scatterometry and Its Validation. IEEE Trans. Geosci. Remote Sens. 2006, 44, 102-107.

52. Wiesmann, A.; Strozzi, T.; Werner, C.; Wegmüller, U.; Santoro, M. Microwave Remote Sensing of Alpine Snow. In IEEE International Symposium on Geoscience and Remote Sensing Proceedings, Barcelona, Spain, 2007; pp. 1223-1227.

53. Bartalis, Z.; Wagner, W.; Naeimi, V.; Hasenauer, S.; Scipal, K.; Bonekamp, H.; Figa, J.; Anderson, C. Initial Soil Moisture Retrievals from the METOP-A Advanced Scatterometer (ASCAT). Geophys. Res. Lett. 2007, 34, L20401.

54. Bourassa, M.A.; Stoffelen, A.; Bonekamp, H.; Chang, P.; Chelton, D.B.; Courtney, J.; Edson, R.; Figa, J.; He, Y.; Hersbach, H.; Hilburn, K.; Jelenak, Z.; Kelly, K.A.; Knabb, R.; Lee, T.; Lindstrom, E.J.; Liu, W.T.; Long, D.G.; Perrie, W.; Portabella, M.; Powell, M.; Rodriguez, E.; Smith, D.K.; Swail, V.; Wentz, F.J. Remotely Sensed Winds and Wind Stresses for Marine Forecasting and Ocean Modeling. In OceanObs 09, Venice, Italy, September 2009; Community White Paper.

(c) 2010 by the author; licensee Molecular Diversity Preservation International, Basel, Switzerland. This article is an open-access article distributed under the terms and conditions of the Creative Commons Attribution license http://creativecommons.org/licenses/by/3.0/. 